\title{
Kinesiotaping in the management of carpal tunnel syndrome
}

\section{Karpal tünel sendromu yönetiminde kinezyobantlama}

\author{
Tuba Tülay Koca ${ }^{1 *}$ (D) \\ 1 Sütçü İmam University, Faculty of Medicine, Department of Physical Medicine and Rehabilitation, Kahramanmaraş, Turkey \\ *Corresponding author: Tuba Tülay Koca E-mail: tuba_baglan@yahoo.com ORCID: 0000-0002-4596-858X \\ Received: 16 April 2018 Accepted: 25 September 2018
}

\begin{abstract}
Aim: Kinesiotaping (KT) is a non-invasive method used for the treatment of pain and muscle dysfunction. In this study we assess the effect of KT on carpal tunnel syndrome (CTS).

Material and Method: A total of 56 patients diagnosed with CTS were randomly selected and KT applicated two times for a period of three days. Results were evaluated before and after the application using the Boston carpal tunnel questionnaire, the visual analog scale (VAS) and the Duruöz hand index.

Results: The mean age of the patients included in the study was $42.9 \pm 11.7$ years, with 41 being female (73.2\%) and 15 male (26.8\%). A majority of the KT applications (83.2\%) were done on the right hand of the patients, $8.9 \%$ were on the left hand, and $1.8 \%$ were bilateral. There was a statistical difference, according to Paired-samples test of VAS, Boston carpal tunnel questionnaire and Duruöz hand index. $(p=0.00 / p=0.000 / p=0.011)$. Moreover, in terms of gender, the Boston function severity score (FSS) after application was statistically higher in the female participants compared to the male participants ( $p$ $=0.047)$.
\end{abstract}

Conclusion: Following the application of KT, pain intensity was reduced, hand function and daily activities were improved for the patients with CTS. Greater improvement was observed after the application with KT in the male patients compared to the female patients.

Keywords: Carpal tunnel syndrome, kinesiotaping, pain, neuropathic pain 


\section{öz}

Amaç: Kinezyobantlama (KT), ağrı ve kas disfonksiyonunun tedavisinde kullanılan noninvazif bir yöntemdir. Bu çalışmada KT'nin karpal tünel sendromu (KTS) üzerindeki etkisini değerlendirdik.

Gereç ve Yöntem: KTS tanılı toplam 56 hasta rastgele seçildi ve iki kez üç gün süreyle KT uygulandı. Bulgular, Boston karpal tünel anketi, görsel analog skala (VAS) ve Duruöz el indeksi kullanılarak uygulamadan önce ve sonra değerlendirildi.

Bulgular: Çalışmaya dahil edilen hastaların yaş ortalaması 42,9 \pm 11,7 yıl, 41'i kadın (\%73,2) ve 15'i erkekti (\%26,8). KT uygulamalarının çoğunluğu $(\% 83,2)$ sağ el, $\% 8,9$ solda ve $\% 1,8$ bilateral olarak yapıldı. VAS, Boston karpal tünel anketi ve Duruöz el indekslerinde eşleştirilmiş örneklem t testine göre istatistiksel olarak anlamlı bir fark vardı $(p=0.00 / p=0.000$ / $\mathrm{p}=0.011$ ). Ayrıca, cinsiyet açısından, uygulama sonrası Boston fonksiyonel şiddet skoru (FSS), kadın katılımcılarda erkek katılımcılara göre istatistiksel olarak daha yüksekti $(p=0.047)$.

Sonuç: KT uygulamasının ardından KTS'li hastalarda ağrı şiddeti azalmış, el fonksiyonu ve günlük aktiviteler iyileşmişti. Erkek hastalarda KT ile uygulama sonrası kadın hastalara göre daha fazla iyileşme gözlendi.

Anahtar kelimeler: karpal tünel sendromu, kinezyobantlama, ağrı, nöropatik ağrı

\section{INTRODUCTION}

Entrapment neuropathy is the result of pressure on a peripheral nerve as it passes through a narrow canal that is bounded by stiff tissues. In spite of their ubiquitous nature, they are underdiagnosed, underreported, and sometimes not properly managed. Entrapment neuropathies are of various types, but the most common type is CTS. Clinical symptoms include pain, numbness and weakness in the hands and ankles [1,2]. Mechanisms involved in the pathophysiology of entrapment neuropathies include mechanical compression and nerve ischemia [3]. Almost half of work-related injuries involve CTS, the results of which cause interruption to work. Conservative methods should be applied in mild to moderate cases, while surgery is recommended for severe cases [1,2].

Kinesiotaping (KT) is an elastic bandage that lifts up the skin, relieving compression to increase blood and lymphatic flow and reduce pain in the muscle and joint injuries [4]. Despite its widespread use in sports, there is only a very limited amount of quality evidence yielded from the studies in the literature that serves to demonstrate the superiority of KT over other elastic bands, and furthermore, there are only a small number of cases showing KT to be a successful treatment option for nerve entrapment neuropathies. Application direction, duration, frequency, and degree of tension related to KT have not yet been described in enough detail to produce a protocol [5]. Well-designed experimental researches are needed to support the use and effectiveness of KT. In the present study, we investigated the efficacy of KT in patients diagnosed with CTS.

\section{MATERIAL AND METHOD}

The study designed as experimental. A total of 56 patients who had been admitted to our Hospital with complaints of hand numbness and/or pain (at least 3 months) and were thereafter diagnosed with CTS clinically and / or through electrophysiological modalities were included in the study. The age, gender, and affected hand of the patients were recorded. To assess the pain complaints of the patients, the visual analog scale (VAS; from $0=$ no pain to $10=$ the worst pain) was used, while for the evaluation of hand functions, the Boston carpal tunnel questionnaire and Duruöz hand index were applied before and at the end of the application. KT was applied 2 times, at least 72 hours period, with 3 days interval. All participants completed the application protocol. An informed consent form was provided from the participants.

Patients were instructed to not remove the band for at least 3 days (except in the case of allergies, discomfort, spontaneous band removal). No other treatment was offered in addition with KT. Patients who were receiving medical treatment or physiotherapy or had undergone surgical treatment for CTS were excluded from the study, as well as those with additional musculoskeletal diseases (cervical pathology, ulnar neuropathy, lateral epicondylitis, fibromyalgia, arthritis) resulting in hand pain or numbness.

\section{KT Application Technique}

Skin cleaning was performed before applying the KT. The application of KT was carried out by the same healthcare professional, as shown in Figure 1. The wrist and 


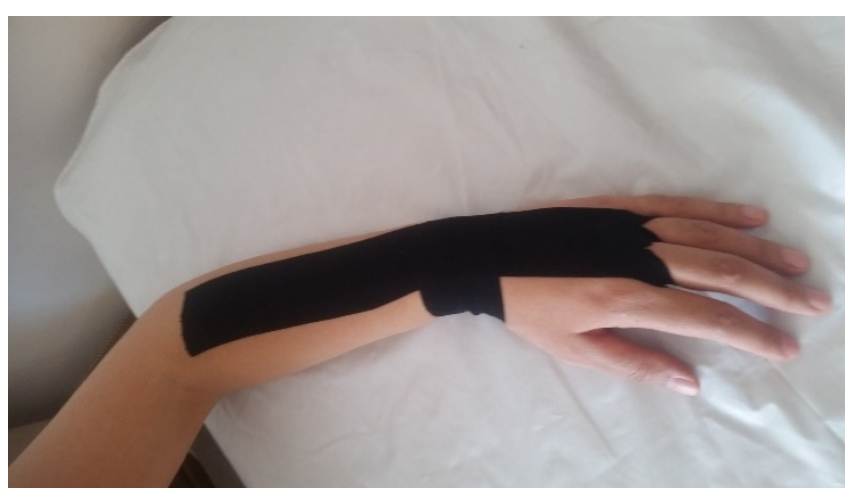

Figure 1. The technique of Kinesiotape application in carpal tunnel syndrome. The vertical band was applied over the third and fourth digits with $50 \%$ mean stretch from the dorsum of the hand up to the wrist, and without any stretch (0\%) from the wrist up to the forearm ( $5 \mathrm{~cm}$ below the medial epicondyle). The strip bonding technique / area correction technique was used to apply vertical band to dorsal surface of the wrist.

metacarpophalangeal joints were at neutral position. Two types of vertical tape, one $30 \mathrm{~cm}$ on average and the other 10-15 cm (Tmax kinesiology tape and Tmax medical, South Korea), were applied over the third and fourth digits. The vertical band was applied with 50\% mean stretch from the dorsum of the hand up to the wrist, and without any stretch (0\%) from the wrist up to the forearm $(5 \mathrm{~cm}$ below the medial epicondyle). The strip bonding technique / area correction technique was used to apply vertical band to dorsal surface of the wrist. Good adhesion of the band was secured via light heat and pressure after application. Application was administered 2 times with 3-day intervals.

\section{Boston Carpal Tunnel Questionnaire}

This questionnaire consists of two sections: Symptom Severity Score (SSS) and Functional Status Score (FSS). The SSS features 11 questions, with responses being scored in a range from one point (mildest) to five points (most severe). The overall result is the calculated mean of all 11 scores. In the FSS section, there are eight questions, and the overall score for functional status is calculated as the mean derived from the point total of all eight questions [6]. Higher symptom severity, or functional status scores, indicate worse symptoms or dysfunction.

\section{Duruöz Hand Index}

The Duruöz hand index includes 18 questions and is used to assess hand disability. The Duruöz hand index was first developed by Duruöz et al. ${ }^{7}$ in 1996 to evaluate rheumatoid hand functions. The 18 questions of the index are divided into 5 categories: kitchen work, dressing, personal hygiene, work place and other activities. The possible responses, along with their attendant points, are as follows: not
Table 1. The descriptive and analytic data for the group

\begin{tabular}{|c|c|c|}
\hline & Mean \pm std $(\mathrm{N}=56)$ & $P$ \\
\hline Age (year) & $\begin{array}{c}42.9 \pm 11.7(\min .16- \\
\max .69)\end{array}$ & \\
\hline Gender (M/F) & $15 / 41$ & \\
\hline $\begin{array}{c}\text { Hand side } \\
\text { (left/right/bilateral) }\end{array}$ & $5 / 50 / 1$ & \\
\hline $\begin{array}{l}{ }^{*} \text { VAS }_{1} \\
\text { VAS }_{2}\end{array}$ & $\begin{array}{c}7.6 \pm 1.4 \\
3.1 \pm 2\end{array}$ & 0.000 \\
\hline $\begin{array}{l}{ }^{*} \mathrm{SSS}_{1} \\
\mathrm{SSS}_{2}\end{array}$ & $\begin{array}{c}4.8 \pm 6.1 \\
2.5 \pm 0.68\end{array}$ & 0.032 \\
\hline $\begin{array}{l}{ }^{*} \mathrm{FSS}_{1} \\
\mathrm{FSS}_{2}\end{array}$ & $\begin{array}{l}2.9 \pm 1.2 \\
2.2 \pm 0.9\end{array}$ & 0.000 \\
\hline $\begin{array}{l}{ }^{*} \text { DURUÖZ } \\
\text { DURUÖZ } \\
\end{array}$ & $\begin{array}{c}22.1 \pm 17.9 \\
14 \pm 13\end{array}$ & 0.000 \\
\hline
\end{tabular}

Abbreviations: M: male; F: female; VAS: visual analog scale; Boston SSS: Boston symptom severity scale; Boston FSS: Boston functional status scale; Duruöz: Duruöz hand index; number 1: before application; number 2: after application. ${ }^{*}$ Paired samples $t$ test: $P<0.005$, statistically significance.

difficulty $(=0)$, very little difficulty $(=1)$, a little difficulty $(=2)$, very difficulty $(=3)$, almost impossible $(=4)$, not able to do $(=5)$. The total score is the sum of the points from the 18 questions (0-90), with higher scores indicating impaired hand functions.

\section{Statistics}

SPSS 17 (SPSS Statistics for Windows, Version 17.0, Chicago: SPSS Inc., USA) was used for statistical analyses. Categorical data are reported as percentages and are compared using the Chi-squared test. Continuous data are reported as mean with standard deviation or median with minimum and maximum and compared using parametric/non-parametric tests according to their normal or anormal distribution. The paired-samples $t$ test was being used to compare variables before and after the application. As a result of the power analysis performed, the minimum number of subjects required was determined as 40 so that the difference of 0.05 units could be meaningful. Type 1 error $=0.01$, power of test: $85 \%$. Statistical significance was considered as $P<0.05$.

\section{RESULTS}

Of the 56 patients included in the study, 41 were female $(73.2 \%)$ and 15 male $(26.8 \%)$, with the age range of all the patients being 16-69 years (mean 42.8 years). A majority of the KT applications (83.2\%) were done on the right hand of the patients, $8.9 \%$ were on the left hand, and $1.8 \%$ were bilateral. The descriptive and analytic data of the group was showed at Table 1.

There were statistically significant difference in the VAS, SSS, FSS and Duruöz hand index scores of the patients before and 


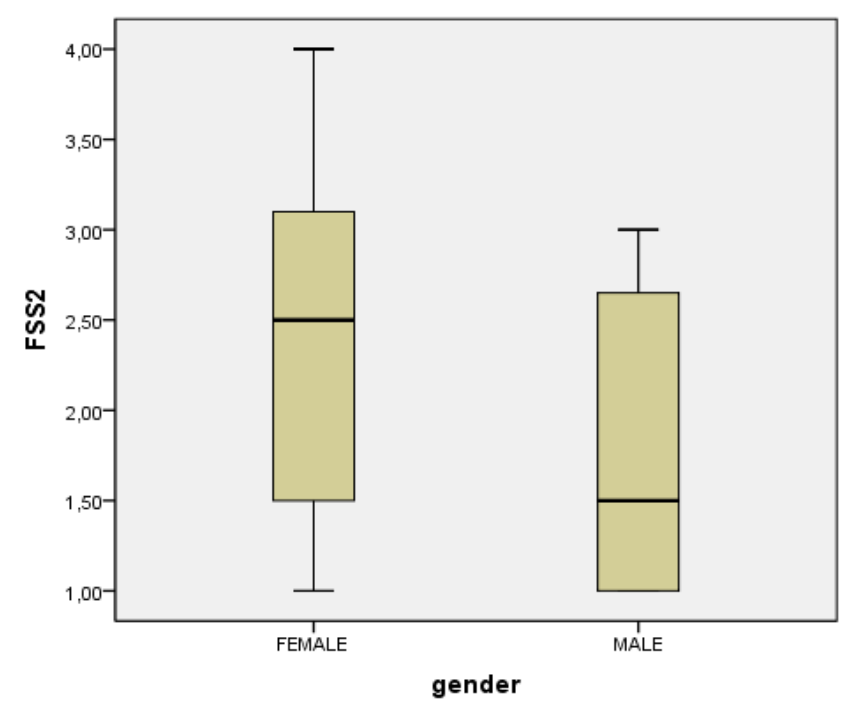

Figure 2. Graphical distribution of funtional status score (FSS) after the KT application according to gender

after KT application in the comparisons performed with the Paired-samples $\mathrm{t}$ test $(p=0.00 / p=0.011 / p=0.00 / p=$ 0.000 ). These differences indicated that KT administration provided significant improvement in pain, symptom severity, and daily hand function.

When analyzed according to gender, the post-application FSS was statistically significantly higher in females $(p=0.047)$ than males. No differences, in terms of gender, were found in other parameters (Figure 2).

\section{DISCUSSION}

CTS, the most common entrapment neuropathy of the upper extremity, is caused by the compression of the median nerve that extends through the carpal tunnel. Typically with CTS, pain and paresthesia of the thumb, the middle finger, and the palmar face of the middle finger close to its radial half are observed. The physical examinations used for the diagnosis of CTS include Flick sign, Phalen maneuver and median nerve compression test [1]. It is a disabling condition, even in its early stages, and negatively affects daily life and quality of life. Magnetic resonance imaging (MRI), ultrasonography (US), as well as diagnostic tests, such as provocative tests and nerve conduction studies, have helped to localize CTS diagnosis and nerve damage [8]. While there is no need for additional tests in patients with typical symptoms, US and electrodiagnostic studies are used for atypical cases and differential diagnosis [1].

Early diagnosis and effective treatment are important to maintain extremity function as the efficacy of many treatment options is limited $[9,10]$. Various conservative treatments (splinting, oral medications, injections, electrotherapy, specific manual techniques, neural shift exercises) are effective in reducing symptoms and improving function in mild to moderate cases [3]. The oral medications used as a part of the conservative treatment approach for CTS include non-steroidal anti-inflammatory drugs, diuretics, vitamin B6, and gabapentin. Other treatment options include local corticosteroid injection, which should be recommended in cases of 4-6 months of no response to treatment. The consequent pain from this may last for 1 month and delay surgery-surgical decompression, endoscopic and open techniques. If surgical decompression is planned, electrodiagnostic testing should first be performed to determine disease severity and prognosis $[1,3,9]$.

KT developed by a chiropractor, Dr. Kenso Kase, in the 1970s, is applied on the skin to assist the body's natural healing process by supporting the structures of the musculoskeletal system, without restricting joint movement. KT lifts the skin up to improve blood and lymphatic flow and thereby reduce pain in muscle and joint injuries [4]. The effect of KT is related to the tension on the skin.

$\mathrm{KT}$ is offered on the market as a personal product. It is made of polymer elastic fibers wrapped in $100 \%$ cotton fibers. The adhesive is $100 \%$ acrylic and heat activated. The acrylic glue has a wavy-like pattern, similar to a fingerprint. KT application involves the placement of an elastic adhesive band to areas of pain or dysfunction. The mechanisms of action include reduction of pain through the stimulation of sensory afferents and ROM enhancement, both of which serve to increase local circulation. Despite the frequent use of KT by athletes in sporting events, there is still insufficient data on its effectiveness $[4,11]$. A meta-analysis conducted in 2013 concluded the same, reporting that there is not enough scientific evidence demonstrating the superiority of KT over other modalities [12]. In a study by De Jesus et al. [13], there was no difference in the effect of KT on muscle strength or performance in different types of injuries.

The effect of KT on muscle strength, endurance and fatigue has been the subject of various research studies, with different results being produced [14]. KT's impact on muscle strength is uncertain. For example, in the study by Karahan et al. [15], it was reported that there was no difference in muscle strength between a group on which KT was applied to the triceps muscles and a control group. In the treatment of myofascial pain syndrome (MPS), KT can also be added to transcutaneous electrical nerve stimulation (TENS) therapy and exercise programs to reduce pain intensity, 
increase pain threshold, and increase function and cervical range of motion (ROM). With the addition of KT application, treatment response was found faster $[16,17]$.

KT has been used as a part of the treatment for various conditions, including metatarsophalangeal instability [18], cerebral palsy [19], shoulder impingement syndrome [20], lower back pain [21], plantar fasciitis [22] and lateral epicondylitis [23]. There is insufficient information on KT efficacy in the treatment of CTS. Kulcu G. et al. [24] compared KT and orthosis effectiveness in 23 CTS patients and found them to have similar effects on pain, grip strength and functional recovery. KT has been shown to have a small beneficial role in increasing muscle strength, proprioception, and ROM [25]. In our study, we found improvement in pain intensity, symptom severity, function and activities of daily living after KT application. Further, the male patients showed more improvement than the female patients in hand function (FSS decline) following KT treatment. This can be attributed to the fact that females tend to have more cases of chronic CTS and more somatic complaints.

\section{Limitation of the Study}

We didn't ask for the severity and the duration of the CTS. It could have been asked which of the mild or severe cases had more benefit from the KT application. Additionally the presence of metabolic causes of CTS just like diabetes mellitus, thyroid disease were not taken into consideration.

\section{CONCLUSION}

CTS is frequently seen and causes disability and work-loss even in its early stages. There is not enough data in the literature about the efficacy and application technique and protocol of KT in the treatment of CTS. It has not been standardized what the applied techniques will be. In our study, we found improvement in pain intensity, symptom severity, hand functions and activities of daily living in CTS patients after 2 applications with our technique. In male patients, further improvement in function after treatment was observed than females.

\section{DECLARATION OF CONFLICT OF INTEREST}

The author declared no conflicts of interest with respect to the authorship and/or publication of this article.

\section{REFERENCES}

1. Wipperman J, Goerl K. Carpal Tunnel Syndrome: Diagnosis and Management. Am Fam Physician 2016; 94 : 993-9.
2. Jiménez Del Barrio S, Bueno Gracia E, Hidalgo García C, et al. Conservative treatment in patients with mild to moderate carpal tunnel syndrome: A systematic review. Neurologia 2016 Jul 22. pii: S0213-4853(16)30094-9. (doi: 10.1016/j.nrl.2016.05.018). [Epub ahead of print]

3. Wahab KW, Sanya EO, Adebayo PB, Babalola MO, Ibraheem HG. Carpal tunnel syndrome and other entrapment neuropathies. Oman Med J 2017; 32: 449-54. (doi: 10.5001/omj.2017.87).

4. Williams S, Whatman C, Hume PA, Sheerin K. Kinesio taping in treatment and prevention of sports injuries: a meta-analysis of the evidence for its effectiveness. Sports Med 2012; 42: 153-64. (doi: 10.2165/11594960000000000-00000).

5. Anandkumar S. Kinesio tape management for superficial radial nerve entrapment: a case report. Physiother Theory Pract 2013; 29: 232-41. (doi:10.3109/09593985.2012.717589). Epub 2012 Aug 27.

6. Levine DW, Simmons BP, Koris MJ, et al. A selfadministered questionnaire fort he assessment of severity of symptoms and functional status in carpal tunnel syndrome. J Bone Surg (Am) 1993; 75: 1585-92.

7. Duruoz MT, Poiraudeau S, Serimanian J, et. al. Development and validation of rheumatord hand functional disability scale that assesses functional handicap. J Rheumatol 1996; 23: 1167-72.

8. Zamborsky R, Kokavec M, Simko L, Bohac M. Carpal tunnel syndrome: symptoms, causes and treatment options. Literature Reviev. Ortop Traumatol Rehabil 2017; 19: 1-8. (doi: 10.5604/ 15093492.1232629).

9. Hobson-Webb LD, Juel VC. Common entrapment neuropathies. Continuum (Minneap Minn) 2017; 23 (2, Selected Topics in Outpatient Neurology): 487-511. (doi: 10.1212/CON. 0000000000000452).

10. İnanç Y, İnanç Y, Halil A, Zülfikar A, Özcan K. Karpal tünel sendromu: 126 olgunun demografik açıdan değerlendirilmesi. J Harran Uni Med Fac 2014; 11: 242-6. $5 p$.

11. Pizac DA, Swanik CB, Glutting JJ, Kaminski TW. Evaluating postural control and ankle laxity between taping and high-top cleats in high school football players. J Sport Rehabil 2016; 19: 1-26. [Epub ahead of print] 
12. Morris D, Jones D, Ryan $H$, Ryan CG. The clinical effects of Kinesio $^{\circledast}$ Tex taping: A systematic review. Physiother Theory Pract. 2013;29(4):259-70. (doi: 10.3109/09593985.2012.731675). Epub 2012 Oct 22.

13. de Jesus JF, Franco YR, Nannini SB, Nakaoka GB, Dos Reis $A C$, Bryk FF. The effects of varıed tensıons of kınesıology tapıng on quadrıceps strength and lower lımb function. Int J Sports Phys Ther 2017; 12: 85-93.

14. Lee NH, Jung HC, Ok G, Lee S. Acute effects of Kinesio taping on muscle function and self-perceived fatigue level in healthy adults. Eur J Sport Sci 2017; 13: 1-8. (doi: 10.1080/17461391. 2017.1294621). [Epub ahead of print]

15. Karahan AY, Yildirim P, Kucuksarac S, et al. Effect of Kinesio taping on elbow muscle strength in healthy individuals: A randomized trial. J Back Musculoskelet Rehabil 2017; 30: 317-23. (doi: 10.3233/BMR-160529).

16. Azatcam G, Atalay NS, Akkaya N, et al. Comparison of effectiveness of transcutaneous electrical nerve stimulation and kinesio taping added to exercises in patients with myofascial pain syndrome. J Back Musculoskelet Rehabil 2017; 30: 291-8. (doi: 10.3233/BMR-150503).

17. Ay S, Konak HE, Evcik D, Kibar S. The effectiveness of Kinesio Taping on pain and disability in cervical myofascial pain syndrome. Rev Bras Reumatol Engl Ed 2017; 57: 93-9. (doi: 10.1016/j. rbre.2016.03.012). Epub 2016 May 10.

18. Peck CN, Macleod A, Barrie J. Lesser metatarsophalangeal instability: presentation, management, and outcomes. Foot Ankle Int 2012; 33: 565-70. (doi: 10.3113/FAI.2012.0001).
19. Shamsoddini A, Rasti Z, Kalantari M, et al. The impact of Kinesio taping technique on children with cerebral palsy. Iran J Neurol 2016; 15: 219-27.

20. Kaya E, Zinnuroglu M, Tugcu I. Kinesio taping compared to physical therapy modalities for the treatment of shoulder impingement syndrome. Clin Rheumatol 2011; 30: 201-7. (doi: 10.1007/s10067-010-1475-6). Epub 2010 Apr 30.

21. Ciosek Z, Kopacz L, Samulak L, Kaźmierczak A, Rotter I. [The influence of kinesiotaping on lumbar spine pain]. Pomeranian J Life Sci 2015; 61: 115-9. [Article in Polish]

22. Ordahan B, Türkoğlu G, Karahan AY, Akkurt HE. Extracorporeal shockwave therapy versus kinesiology taping in the management of plantar fasciitis: A Randomized Clinical Trial. Arch Rheum 2017; 32: 227-33. (doi:10.5606/ArchRheumatol.2017.6059).

23. Shakeri $H$, Soleimanifar $M$, Arab AM, Hamneshin Behbahani S. The effects of KinesioTape on the treatment of lateral epicondylitis. J Hand Ther 2017 Feb 27. pii: S0894-1130(17)30005-4. (doi: 10.1016/j.jht.2017.01.001). [Epub ahead of print]

24. Geler Külcü D, Bursali C, Aktaş İ, Bozkurt Alp S, Ünlü Özkan F, Akpinar P. Kinesiotaping as an alternative treatment method for carpal tunnel syndrome. Turk J Med Sci 2016; 46: 1042-9. (doi: 10.3906/sag-1503-4).

25. Dilek B, Batmaz I, Sarıyıldız MA, et al. Kinesio taping in patients with lateral epicondylitis. J Back Musculoskelet Rehabil 2016;29: 853-8. 